\title{
Purification and Some Properties of Sucrose Phosphorylase from Leuconostoc mesenteroides
}

\author{
Takuro Koga, Kazuo NaKamura, Yoshio Shirokane, \\ Kiyoshi Mizusawa, Satoshi Kitao and Mamoru Kikuchi \\ Research and Development Division, Kikkoman Corporation, \\ 399 Noda, Noda-shi, Chiba 278, Japan \\ Received January 17,1991
}

\begin{abstract}
Sucrose phosphorylase (EC 2.4.1.7) was purified to homogeneity from Leuconostoc mesenteroides cells with a specific activity of $\mathbf{1 7 3 . 8}$ units per $\mathbf{m g}$ protein by ammonium sulfate fractionation, anion exchange HPLC on TSKgel DEAE-5PW, and hydrophobic HPLC on TSKgel Ether-5PW.

The purified enzyme was an acidic protein having an isoelectric point of $\mathrm{pH} 4.6$ and $s_{20, w}^{0}$ of 4.34 S. The molecular weight of this enzyme was estimated to be 56,400 by sedimentation equilibrium, 55,000 by SDS-polyacrylamide gel electrophoresis, and HPLC gel filtration on TSKgel G3000SW, suggesting that the enzyme is a monomeric protein. With regard to molecular weight, amino acid composition, and N-terminal amino acid sequence of 30 residues, this enzyme is close to the glucosyltransferase A of Streptococcus mutans.
\end{abstract}

Sucrose phosphorylase (EC 2.4.1.7) was first reported to be found in Leuconostoc mesenteroides by Kagan et al., ${ }^{11}$ and subsequently found in a few microorganisms. ${ }^{2)}$ Recently Russell et al. reported that glucosyltransferase A produced by Streptococcus mutans was identified as sucrose phosphorylase, ${ }^{3)}$ and a complete nucleotide sequence was identified. ${ }^{4)}$

Sucrose phosphorylase has plenty of biotechnological uses in sucrose production from starch, ${ }^{5,6)}$ in enzymatic assay for sucrose, ${ }^{7)}$ in synthesis of ${ }^{14} \mathrm{C}$-labeled sucrose, ${ }^{8)}$ in the specific measurement of inorganic phosphate ${ }^{2,9)}$ and so on. L. mesenteroides has a significant advantage in the microbiological production of sucrose phosphorylase, because crude extracts of this organism had much higher total and specific activities than those of Pseudomonas saccharophila and Pseudomonas putrefaciens. ${ }^{10)}$ Furthermore, Vandamme et $a l .{ }^{11)}$ investigated the fermentation conditions that affect sucrose phosphorylase production by L. mesenteroides in detail, and Guibert et al. applied it to glucose-1-phosphate production by the immobilized enzyme technique. ${ }^{12)}$

On the other hand, sucrose phosphorylase produced by $P$. saccharophila has been purified and fully characterized. ${ }^{13)}$ However, relatively little is known about the physico-chemical properties of sucrose phosphorylase from $L$. mesenteroides, which could be most useful in industrial use.

In this report, we studied some physicochemical properties of a sucrose phosphorylase purified from $L$. mesenteroides, and found that this enzyme was different from $P$. saccharophila enzyme, and close to glucosyltransferase A of S. mutans.

\section{Materials and Methods}

Chemicals. Except as noted otherwise, all chemicals were from Wako Pure Chemical Industries, Osaka. Glucose-1,6diphosphate, phosphoglucomutase, D-gluconate-6-phosphate, and $M_{\mathrm{r}}$ marker proteins for SDS-polyacrylamide gel electrophoresis were obtained from Boehringer Mannheim Yamanouchi, Tokyo. Nicotinamide adenine dinucleotide phosphate oxidized form $\left(\mathrm{NADP}^{+}\right)$, glucose6-phosphate dehydrogenase, and $M_{r}$ marker proteins for HPLC gel filtration were obtained from Oriental Yeast Co., Tokyo. TSKgel DEAE-5PW, TSKgel Ether-5PW, and TSKgel G3000SW columns were products of Tosoh, Tokyo.

Organism and cultivation. L. mesenteroides ATCC 12291 
was used in this study. The organism was grown at $30^{\circ} \mathrm{C}$ for $16 \mathrm{hr}$ with slow agitation in a 30 -liter jar fermenter containing 201 of culture medium modified that of De Moss et al. ${ }^{14)}$ It consists of $2 \%$ sucrose, $1.5 \%$ polypepton, $1.5 \%$ yeast extract, $1.5 \% \mathrm{~K}_{2} \mathrm{HPO}_{4}, 0.5 \%$ L-lysine monohydrochloride, $0.04 \% \quad \mathrm{MgSO}_{4} \cdot 7 \mathrm{H}_{2} \mathrm{O}, 0.001 \% \mathrm{FeSO}_{4}$. $7 \mathrm{H}_{2} \mathrm{O}, 0.02 \% \mathrm{MnSO}_{4} \cdot 7 \mathrm{H}_{2} \mathrm{O}, 0.001 \%$ thiamine hydrochloride, and $0.005 \%$ ascorbic acid ( $\mathrm{pH} 7.8$ ). The cells of an overnight culture were harvested by centrifugation at $8,000 \mathrm{rpm}$ for $30 \mathrm{~min}$ and stored at $-20^{\circ} \mathrm{C}$.

Enzyme assay. Sucrose phosphorylase activity was measured by the method of Silverstein et $a l .,{ }^{13}$ in which the production of glucose-1-phosphate from sucrose and inorganic phosphate is coupled to the reduction of $\mathrm{NADP}^{+}$ in the presence of phosphoglucomutase and glucose-6phosphate dehydrogenase. The standard assay medium contained $50 \mathrm{~mm}$ of potassium phosphate buffer ( $\mathrm{pH} 6.8$ ), $140 \mathrm{~mm}$ sucrose, $1 \mathrm{~mm}$ EDTA-2Na, $150 \mathrm{~mm} \mathrm{MgCl}_{2}, 1 \mathrm{mg}$ of $\mathrm{NADP}^{+}, 1 \mu \mathrm{g}$ of glucose-1,6-diphosphate, $100 \mu \mathrm{g}$ of phosphoglucomutase, 20 units of glucose-6-phosphate dehydrogenase, and the enzyme solution $(20 \mu \mathrm{l})$ in a final volume of $3.3 \mathrm{ml}$. Increase in adsorption of $\mathrm{NADPH}$ at $340 \mathrm{~nm}$ was measured at $25^{\circ} \mathrm{C}$. One unit of sucrose phosphorylase activity was defined as the amount of enzyme which caused the reduction of $1 \mu \mathrm{mol}$ of $\mathrm{NADP}^{+}$ per min under the above assay conditions. An extinction coefficient of $6.22 \times 10^{3} \mathrm{M}^{-1} \mathrm{~cm}^{-1}$ was used for calculation.

Measurement of protein. Protein was measured by the method of Lowry et al., ${ }^{15}$ using bovine serum albumin as the standard protein.

HPLC gel filtration. The estimation of the molecular weight of sucrose phosphorylase by HPLC gel filtration on TSKgel G3000SW (7.15 mm i.d. $\times 60 \mathrm{~cm} \times 2$ ) were done by the method of Fukano et al. ${ }^{16)}$

Electrophoresis. The molecular weight was measured using sodium dodecylsulfate (SDS) polyacrylamide gel electrophoresis by the method of Laemmli. ${ }^{17}$ A SDS-polyacrylamide gradient slab gel (10-20\%; Daiichi Kagaku Yakuhin, Tokyo) was used. The gel was stained with $0.25 \%$ Coomassie Brilliant Blue R-250.

Isoelectric focusing. Isoelectric focusing on polyacrylamide gel was done using carrier ampholite ( $\mathrm{pH} 3-10$, Ampholine, LKB, Bromma, Sweden) by the method of Catsimpoolas. ${ }^{18)}$

Ultracentrifugal analysis. All sedimentation experiments were done with a Hitachi UCA-1A analytical ultracentrifuge. Sedimentation coefficients were corrected to standard conditions and extrapolated to infinite dilution as described by Schachman. ${ }^{19}$ ) Sedimentation equilibrium study was analyzed by interference optics by the method of Richards and Schachman. ${ }^{20}$ The partial specific volume for the enzyme was calculated from the amino acid composition. ${ }^{19)}$

Amino acid composition and $\mathrm{N}$-terminal amino acid sequence. Amino acid analysis of the enzyme was done using a Hitachi amino acid analyzer model L-8500. The enzyme was hydrolyzed by the method of Simpson et al. ${ }^{21)}$ in $4 \mathrm{~N}$ methanesulfonic acid under vacuum at $110^{\circ} \mathrm{C}$ for 24,48 , and $72 \mathrm{hr}$. The sequence of the first 30 amino acid residues at the $\mathrm{N}$-terminus of the enzyme was analyzed on an Applied Biosystems 470A gas phase sequencer. Phenylthiohydantoin derivatives were identified by reverse phase chromatography with an on-line Applied Biosystems $120 \mathrm{~A}$ PTH-analyzer.

\section{Results}

\section{Purification of sucrose phosphorylase}

All the procedures for isolation and purification of the enzyme were done at $0-4^{\circ} \mathrm{C}$. Cells were harvested from 101 of culture broth by centrifugation at $8,000 \mathrm{rpm}$ and washed with $50 \mathrm{~mm}$ potassium phosphate buffer $(\mathrm{pH} 6.5)$. The cells were suspended in 11 of the same buffer. After addition of $0.1 \%$ lysozyme, $0.1 \%$ Triton X-100, and $10 \mathrm{~mm}$ EDTA-2Na, the solution was incubated at $37^{\circ} \mathrm{C}$ for $1 \mathrm{hr}$ and centrifuged for $10 \mathrm{~min}$ at $12,000 \mathrm{rpm}$.

Nucleic acids in the supernatant solution were precipitated by forming an aggregate with polyethyleneimine. The precipitate was removed by centrifugation. The supernatant solution was brought to $35 \%$ saturation of ammonium sulfate by addition of neutral saturated ammonium sulfate solution. After $1 \mathrm{hr}$, the precipitate was removed by centrifugation and the supernatant was brought to $75 \%$ saturation of ammonium sulfate. The resulting precipitate was collected by centrifugation and dissolved in $10 \mathrm{ml}$ of $10 \mathrm{~mm} 2-(\mathrm{N}$-morpholino)ethanesulfonic acid (MES) buffer ( $\mathrm{pH} \mathrm{6.0)}$. The solution was dialyzed against the same buffer overnight and centrifuged. The precipitate was discarded.

The supernatant $(1 \mathrm{ml})$ was put onto a TSKgel DEAE-5PW column $(21.5 \mathrm{~mm}$ i.d. $\times$ $15 \mathrm{~cm}$ ) previously equilibrated with $10 \mathrm{~mm}$ MES buffer ( $\mathrm{pH}$ 6.0). The column was washed with $10 \mathrm{~mm}$ MES buffer containing $0.1 \mathrm{M} \mathrm{KCl}$, and eluted with a linear gradient of $\mathrm{KCl}$ from 
$0.1 \mathrm{M}$ to $0.3 \mathrm{M}$ for $60 \mathrm{~min}$ in the same buffer at a flow rate of $6 \mathrm{ml} / \mathrm{min}$. The active fractions obtained from 20 runs of the DEAE-5PW chromatography were pooled and concentrated to about $20 \mathrm{ml}$ by ultrafiltration, and were dialyzed overnight against $0.1 \mathrm{M}$ potassium phosphate buffer containing $1.5 \mathrm{M}$ ammonium sulfate ( $\mathrm{pH} 7.0)$, and centrifuged.

The supernatant $(1 \mathrm{ml})$ was put onto a TSKgel Ether-5PW column $(21.5 \mathrm{~mm}$ i.d. $\times 15$ $\mathrm{cm})$ previously equilibrated with $1.5 \mathrm{M}$ ammonium sulfate in the same buffer. The column was washed with the same buffer, and eluted with a linear gradient of ammonium sulfate from $1.5 \mathrm{M}$ to zero for $60 \mathrm{~min}$ in the same buffer at a flow rate of $6 \mathrm{ml} / \mathrm{min}$. The elution pattern is shown in Fig. 1. The active fractions from 30 runs of this chromatography were pooled and concentrated to about $10 \mathrm{ml}$ by ultrafiltration, and used as the purified enzyme preparation.

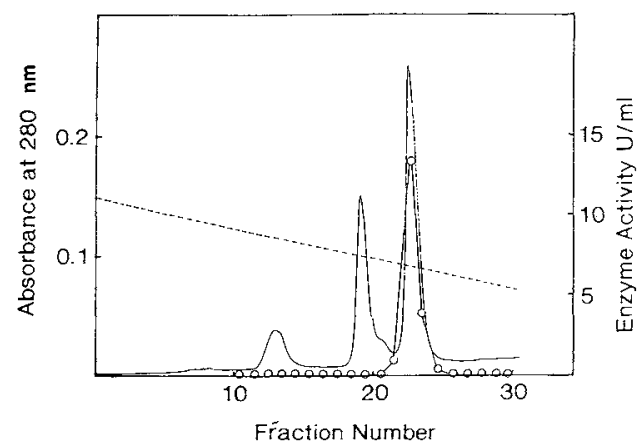

Fig. 1. Hydrophobic Chromatography of Sucrose Phosphorylase from L. mesenteroides through TSKgel Ether5PW.

Fractions of $6 \mathrm{ml}$ were collected from a linear gradient (----) of ammonium sulfate $(1.5-0.75 \mathrm{M})$, and enzyme activity $(\mathrm{O}-\mathrm{O})$ and absorbance at $280 \mathrm{~nm}(\longrightarrow)$ were measured.
A typical purification is summarized in Table I. The overall purification was approximately 25 -fold with a yield of $17 \%$.

\section{Homogeneity}

The purified enzyme preparation gave a single protein band on SDS-polyacrylamide gel electrophoresis (Fig. 2A). Sedimentation velocity experiments showed that the protein

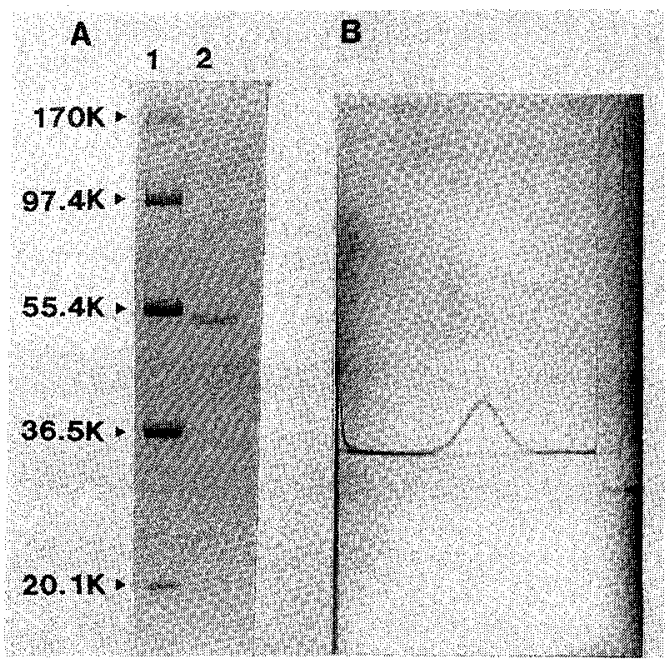

Fig 2. SDS-Polyacrylamide Gel Electrophoresis (A) and Sedimentation Pattern (B) of Purified Sucrose Phosphorylase.

(A) About $20 \mu \mathrm{g}$ of the purified enzyme was electrophoresed on lane 2.

Lane 1 was maker proteins; $\alpha 2$ macroglobulin $\left(M_{r}=\right.$ 170,000 reduced), phosphorylase b $\left(M_{r}=97,400\right)$, glutamate dehydrogenase $\left(M_{r}=55,400\right)$, lactate dehydrogenase $\left(M_{r}=36,500\right)$, trypsin inhibitor $\left(M_{r}=20,100\right.$, soybean $)$.

(B) The protein concentration was $11.9 \mathrm{mg} / \mathrm{ml}$ in $10 \mathrm{~mm}$ potassium phosphate buffer containing $0.1 \mathrm{M}$ potassium chloride. The temperature was $20^{\circ} \mathrm{C}$ and bar angle was $70^{\circ}$. The photograph was taken at $80 \mathrm{~min}$ after attainment of $55,430 \mathrm{rpm}$.

Table I. Purification of Sucrose Phosphorylase from L. mesenteroides

\begin{tabular}{lcccc}
\hline \multicolumn{1}{c}{ Step } & $\begin{array}{c}\text { Total protein } \\
(\mathrm{mg})\end{array}$ & $\begin{array}{c}\text { Total activity } \\
\text { (units) }\end{array}$ & $\begin{array}{c}\text { Specific activity } \\
\text { (units/mg) }\end{array}$ & $\begin{array}{c}\text { Yeild } \\
(\%)\end{array}$ \\
\hline Crude extracts $^{a}$ & 2605.6 & 18,500 & 7.1 & 100 \\
$\left(\mathrm{NH}_{4}\right)_{2} \mathrm{SO}_{4}(35-75 \%$ satn.) & 680.9 & 8492 & 12.5 & 45.9 \\
DEAE-5PW HPLC & 41.5 & 5275 & 127.1 & 28.5 \\
Ether-5PW HPLC & 18.2 & 3145 & 173.8 & 17.0 \\
\hline
\end{tabular}

a Crude extracts were from cultured cells from 101 of broth. 


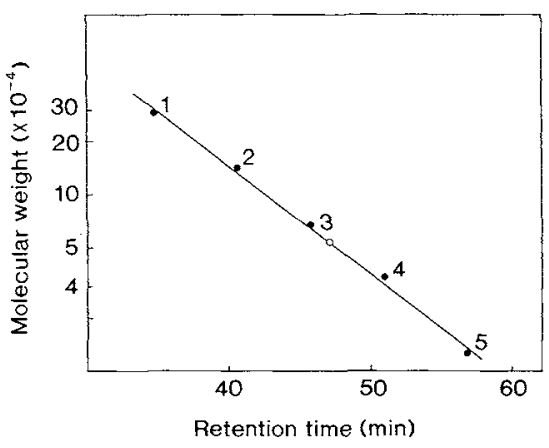

Fig. 3. Measurement of the Molecular Weight of Sucrose Phosphorylase by HPLC Gel Filtration on TSKgel G3000SW.

Closed circle, (1) glutamate dehydrogenase $\left(M_{r}=290,000\right)$; (2) lactate dehydrogenase $\left(M_{r}=142,000\right)$; (3) enolase $\left(M_{r}=67,000\right)$; (4) adenylate kinase $\left(M_{r}=32,000\right)$; (5) cytochrome $c\left(M_{r}=12,400\right)$; open circle, sucrose phosphorylase.

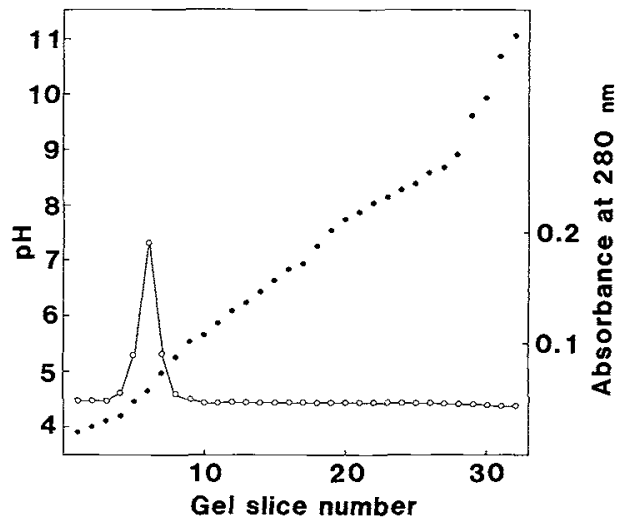

Fig. 4. Isoelectric Focusing of Sucrose Phosphorylase in a Polyacrylamide Gel Column.

About $60 \mu \mathrm{g}$ of purified enzyme was put on the column. After the electrophoresis, the gel was cut into $2 \mathrm{~mm}$ slices. Each slice was extracted with $0.5 \mathrm{ml}$ of distilled water for $4 \mathrm{hr}$ at $5^{\circ} \mathrm{C}$, and then $\mathrm{pH}$ and absorbance at $280 \mathrm{~nm}$ of the extract were measured.

Open circles, absorbance at $280 \mathrm{~nm}$; closed circles, $\mathrm{pH}$.

was a single component with $s_{20, w}^{\mathrm{o}}$ of $4.34 \mathrm{~S}$, as shown in Fig. 2B.

\section{Molecular weight}

The molecular weight of the purified enzyme was measured by sedimentation equilibrium ultracentrifugation, HPLC gel filtration, and SDS-polyacrylamide gel electrophoresis. Tak-
Table II. Amino Acid Composition of Sucrose PHOSPHORYLASE OF L. mesenteroides AND Glucosyltransferase A of $S$. mutans

\begin{tabular}{lrrr} 
& mol $(\%)$ & \multicolumn{2}{c}{ Residues } \\
\cline { 3 - 4 } Amino acid & SPL & SPL $^{a}$ & gtfA $^{b}$ \\
\hline Aspartic acid + Asparagine & 16.0 & 77 & 71 \\
Threonine & 8.1 & 40 & 29 \\
Serine & 5.0 & 25 & 22 \\
Glutamic acid + Glutamine & 10.1 & 48 & 52 \\
Glycine & 5.0 & 28 & 23 \\
Alanine & 7.9 & 41 & 33 \\
Cysteine + Cystine & n.d. & n.d. & $1^{d}$ \\
Valine & 5.4 & 26 & 28 \\
Isoleucine & 5.9 & 29 & 33 \\
Leucine & 8.1 & 39 & 41 \\
Tyrosine & 5.1 & 24 & 31 \\
Phenylalanine & 4.7 & 22 & 24 \\
Lysine & 6.6 & 31 & 33 \\
Histidine & 2.0 & 10 & 11 \\
Tryptophan & 1.4 & 6 & 6 \\
Arginine & 3.2 & 15 & 19 \\
Proline & 3.4 & 17 & 15 \\
Methionine & 2.0 & 10 & 9 \\
Total & & 488 & 481 \\
\hline
\end{tabular}

a SPL: sucrose phosphorylase Calculated based on a molecular weight of 55,000 .

${ }^{b}$ gtfA: glucosyltransferase A by Ferretti et al. ${ }^{4 \text { ) }}$

c n.d.: not detected

d Cysteine residue

ing a partial specific volume, $0.73 \mathrm{ml} / \mathrm{g}$, estimated from the amino acid composition (Table II), the molecular weight was found to be 56,400 by sedimentation equilibrium studies. The molecular weight was also estimated to be 55,000 by HPLC gel filtration on a TSKgel G3000SW column as shown Fig. 3. From electrophoresis in the presence of $1 \%$ SDS, the molecular weight of sucrose phosphorylase was estimated to be 55,000 (Fig. 2A).

\section{Isoelectric point}

The isoelectric point of the enzyme was $\mathrm{pH}$ 4.6 by isoelectric focusing, as shown in Fig. 4.

\section{Amino acid composition and $N$-terminal amino acid sequence}

The amino acid composition of the enzyme is shown in Table II. Cysteine and cystine were 


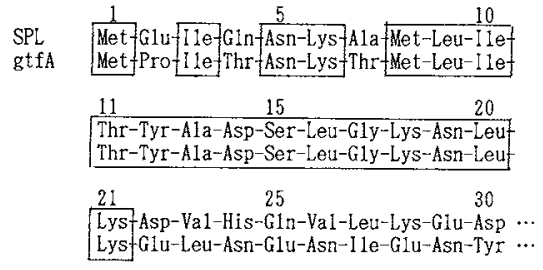

Fig. 5. Comparison of $\mathrm{N}$-Terminal Amino Acid Sequence of 30 Residues.

The upper sequence (SPL, sucrose phosphorylase) is the result of this report. The lower sequence (gtfA, glucosyltransferase $\mathrm{A}$ ) is the deduced sequence based on the nucleotide sequence. ${ }^{4)}$ Positions where identical amino acids are found in the alignment of two enzymes are boxed.

not detected. The N-terminal amino acid of the enzyme was methionine. The sequence of the first 30 amino acid residues at the $\mathrm{N}$-terminus of the enzyme is given and compared with the deduced amino acid sequence of glucosyltransferase A in Fig. 5.

\section{Discussion}

In this study, sucrose phosphorylase was purified from L. mesenteroides and some of its physico-chemical properties studied. The proteins eluted from TSKgel DEAE-5PW displayed two main bands on SDS-polyacrylamide gel electrophoresis (data not shown). One corresponded to sucrose phosphorylase, and the other was a $79 \mathrm{kDa}$ protein. In further purification, it was hard to separate these two proteins by HPLC gel filtration on TSKgel G3000SW and hydroxylapatite chromatography on TSKgel HA-1000. As a result, we succeeded in the purification of the enzyme by HPLC hydrophobic chromatography on TSKgel Ether-5PW. The purity of this enzyme was demonstrated in both SDS-polyacrylamide gel electrophoresis and sedimentation velocity analysis.

These results showed that sucrose phosphorylase of $L$. mesenteroides was a monomeric protein with a molecular weight of 55,000 composed of 488 amino acids. Its isoelectric point was at $\mathrm{pH} 4.6$. With regard to molecular weight, this enzyme was close to glucosyl- transferase A of $S$. mutans, having a molecular weight of 55,665 composed of 481 amino acids, ${ }^{4)}$ but distinct from the enzymes of $P$. saccharophila $\left(M_{r}=84,000\right)^{13}$ and Clostridium pasteurianum $\left(M_{r}=35,600\right) .{ }^{2)}$ Silverstein et al. reported that sucrose phosphorylase of $P$. saccharophila was a dimeric protein having a sedimentation constant of $5.2 \mathrm{~S},{ }^{13}$ ) but that of L. mesenteroides was $4.34 \mathrm{~S}$. In a comparison of the sequence of the first 20 amino acid residues at the $\mathrm{N}$-terminus on this enzyme with those on glucosyltransferase A showed that 17 of 20 residues were identical. We further compared 30 residues on this enzyme with the deduced amino acid sequence based on nucleotide sequence of glucosyltransferase A; 18 of 30 residues were identical. Furthermore amino acid composition of this enzyme was quite similar to that of glucosyltransferase A. In addition, cysteine and cystine were not detected in amino acid analysis of sucrose phosphorylase, on the other hand only one cysteine residue was detected on glucosyltransferase $\mathrm{A},{ }^{4)}$ suggesting that both enzymes have no disulfide bonds. These results indicate that this enzyme is similar to glucosyltransferase $\mathrm{A}$, but not to $P$. saccharophila enzyme. Comparison of the complete amino acid sequence with the sucrose phosphorylase of $L$. mesenteroides appears to be untimely because only limited information is available.

We have purified this enzyme from $L$. mesenteroides to use for the enzymatic measurement of inorganic phosphate. A large scale fermentation is required for supplying the enzyme for commercial diagnostic use, because of its low productivity. Therefore we are cloning the sucrose phosphorylase gene from L. mesenteroides for constructing an highproducing strain to resolve this problem.

Acknowledgments. We thank Dr. T. Horiuchi and Mr. H. Takei for their support and encouragement. Thanks are also due to Ms. E. Yamazaki and Ms. T. Kurokawa for their help in the amino acid analysis and isoelectric focusing. 


\section{References}

1) B. O. Kagan, S. N. Latker and E. M. Zfasman, Biokhimiya, 7, 93 (1942).

2) E. J. Vandamme, J. V. Loo, L. Machtelinskx and A. D. Laporte, in "Advances in Applied Microbiology," Vol. 32, ed. by A. I. Laskin, Academic Press, New York, 1987, pp. 163-201.

3) R. R. B. Russell, H. Mukasa, A. Shimamura and J. J. Ferretti, Infect. Immun., 56, 2763 (1988).

4) J. J. Ferretti, T. T. Huang and R. R. B. Russell, Infect. Immun., 56, 1585 (1988).

5) S. J. Kelly and L. G. Butler, Biotechnol. Bioeng., 22, $1501(1980)$.

6) S. D. Larroque, L. Hammar and W. J. Whelan, J. Appl. Biochem., 4, 133 (1982).

7) P. R. Birnberg and M. L. Brenner, Anal. Biochem., 142, 556 (1984).

8) B. M. Chassy and M. I. Krichevsky, Anal. Biochem., 49, 232 (1972).

9) Y. Katayama and J. Nishimura, Japan Kokai Tokkyo Koho, 63-49100 (Mar. 1, 1988).

10) R. Weimberg and M. Doudoroff, J. Bacteriol., 68 ,
381 (1954).

11) E. J. Vandamme, J. V. Loo and A. D. Laporte, Biotechnol. Bioeng., 29, 8 (1987).

12) A. Guibert and P. Monsan, Ann. N.Y. Acad. Sci., 542, 307 (1987).

13) R. Silverstein, J. Voet, D. Reed and R. H. Abeles, J. Biol. Chem., 242, 1338 (1967).

14) R. D. D. Moss, R. C. Bard and I. C. Gunsalus, $J$. Bacteriol., 62, 499 (1951).

15) O. H. Lowry, N. J. Rosebrough, A. L. Farr and R. J. Randall, J. Biol. Chem., 193, 265 (195I).

16) K. Fukano, K. Komiya, H. Sasaki and T. Hashimoto, J. Chromatogr., 166, 47 (1978).

17) U. K. Laemmli, Nature, 227, 680 (1970).

18) N. Catsimpoolas, Anal. Biochem., 26, 480 (1968)

19) H. K. Schachman, in "Methods in Enzymology," Vol. 4, ed. by S. P. Colowick and N. O. Kaplan, Academic Press, New York, 1957, pp. 32-103.

20) E. G. Richards and H. K. Schachman, J. Phys. Chem., 63, 1578 (1959).

21 R. J. Simpson, M. R. Neuberger and T. Y. Liu, $J$. Biol. Chem., 251, 1936 (1976). 